\section{Applications of acoustic radiation force impulse quantification in chronic kidney disease: a review}

\author{
Liang Wang \\ Department of Ultrasound, Chinese Academy of Medical Sciences and Peking Union Medical \\ College Hospital, Beijing, China
}

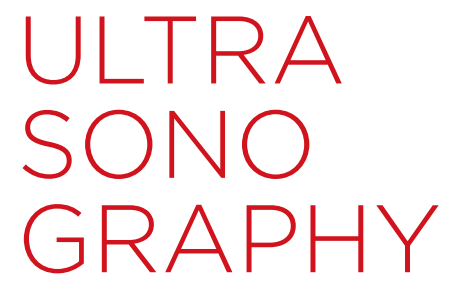

REVIEW ARTICLE

http://dx.doi.org/10.14366/usg. 16026 pISSN: 2288-5919 - elSSN: 2288-5943 Ultrasonography 2016;35:302-308

Received: May 23, 2016

Revised: July 10, 2016

Accepted: July 18, 2016

Correspondence to: Liang Wang, MD, Department of Ultrasound, Chinese Academy of Medical Sciences and Peking Union Medical College Hospital, 1 Shuaifuyuan Wangfujing, Beijing 100730, China

Tel. +86-10-69155494

Fax. $+86-10-69155494$

E-mail: bryan_pumch@163.com

\section{Introduction}

Ultrasound-based elastography is one of the most remarkable advances in the field of medical ultrasonography in recent decades, and it has greatly expanded the utility of ultrasonography in clinical practice. The biophysical information provided by ultrasonic elastography has led to its widespread use in the management of various diseases involving tissue stiffness, such as solid tumors, fibrosis associated with liver cirrhosis, and atheromas and calcifications associated with arteriosclerosis [1]. In 2015, the World Federation for Ultrasound in Medicine and Biology released guidelines and recommendations for the clinical use of ultrasound-based elastography, with a special focus on chronic liver disease (CLD) as an example of diffuse disease and on breast tumors as examples of focal lesions [2,3]. Acoustic radiation force impulse (ARFI) imaging is an emerging technique with great promise in the field of ultrasonic elastography.

In ARFI imaging, an ultrasound probe creates a focused "push" pulse, which can induce tissue deformation in the region of interest (ROI). As a result, shear waves are generated and propagate away from the ROI. The same transducer is then used to monitor the propagation of the shear waves by radiofrequency-echo tracking, and ultimately displays their velocity $(\mathrm{m} / \mathrm{sec})$. Assuming that a given tissue displays simple physical behavior (i.e., linear, isotropic, and homogeneous), the speed of
This is an Open Access article distributed under the terms of the Creative Commons Attribution NonCommercial License (http://creativecommons.org/ licenses/by-nc/3.0/) which permits unrestricted noncommercial use, distribution, and reproduction in any medium, provided the original work is properly cited.

Copyright @ 2016 Korean Society of Ultrasound in Medicine (KSUM)

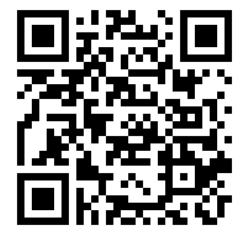

How to cite this article:

Wang L. Applications of acoustic radiation force impulse quantification in chronic kidney disease: a review. Ultrasonography. 2016 Oct;35(4):302-308. 
shear waves is related to the underlying stiffness of the material. Specifically, shear waves propagate faster through stiffer tissue.

ARFI imaging has many advantages over previously used strain elastography techniques. First, since the acoustic radiation force pulses automatically induce tissue displacement, ARFI imaging is not operator-dependent and can determine tissue elasticity quantitatively, whereas strain elastography can only determine qualitative and relative elasticity. Moreover, ARFI imaging does not rely on transducer compression, as strain elastography does, and it can therefore be applied to visualize deep organs, for which it is difficult to generate sufficient deformation via compression from the surface of the body.

Due to these remarkably promising characteristics, multiple studies have been carried out over the last decade to explore the application of ARFI imaging in kidney disease. With study populations ranging from healthy individuals to allograft patients, many promising results have been published, which have encouraged clinicians and researchers to explore the role of ARFI in chronic kidney disease (CKD). ARFI quantification as a method of estimating fibrosis has been validated in patients with CLD. As in CLD, fibrosis is the principal process underlying the progression of $C K D$, which displays a relatively uniform response involving glomerulosclerosis, tubular atrophy, interstitial fibrosis, and changes in the renal vasculature [4].

CKD is defined as abnormalities of kidney structure or function present for 3 months with implications for health. CKD comprises a group of pathologies, and is a progressive and irreversible syndrome that starts asymptomatically, continues through renal dysfunction, and ultimately leads to renal failure [5]. The incidence of CKD has increased significantly over recent decades, and its prevalence is estimated to be $8 \%-16 \%$ worldwide [6]. CKD has recently emerged as an increasingly significant public health issue. In particular, the risk of cardiovascular disease is notably greater in individuals with CKD. Diabetes and hypertension are the leading causes of CKD, although autoimmunity, atherosclerosis, infections, drugs and toxins, obstruction of the urinary tract, genetic defects, and other factors may initiate the disease [6].

To date, several studies on ARFI quantification in CKD have been published (Table 1) [7-18]. The aim of the present review was to identify points of agreement and disagreement on this topic and to outline possible avenues of future research.

\section{Procedure of ARFI Quantification}

Table 1 summarizes previously published studies on ARFI quantification in CKD patients. Variations in the procedure of ARFI quantification were present among the studies, but the following commonalities were nonetheless observed (Fig. 1): (1) the kidney was displayed on the longitudinal plane to identify the intrarenal structures of the cortex, medulla, and sinus; (2) the sample volume (ROI) was located exclusively in the cortical region; (3) the sample line was radially oriented; (4) the applied transducer compression was minimized as much as possible; (5) patients were asked to hold their breath during the measurements; and (6) shear-wave velocity (SWV) measurements were repeated 5-10 times.

The above requirements had the goal of reducing the impact of renal anisotropy and other technical factors affecting the quality of the measurements, and thereby improving the reproducibility of SWV measurements. Unfortunately, these requirements appeared insufficient for achieving this goal. Two important factors should not be ignored in the standardization of ARFI quantification. First, although the sample volume was located exclusively in the cortical region, the ROI was allowed to encompass any part of the kidney (i.e., the upper, middle, or lower third). However, this may lead to violations of the requirement for the sample line to be radially oriented, particularly when sampling the renal cortex at the upper and lower parts of the kidney. Radial sampling has the goal of avoiding the effects of the anisotropic properties of the kidney, as non-radial orientations are susceptible to renal anisotropy, which may compromise the reproducibility of the measurements. Second, the position of the patient is an often-underestimated factor influencing the reproducibility of the measurements. In B-mode scans, patients must be turned with varying degrees of obliquity in order to obtain complete images of both kidneys. The literature on ARFI quantification indicates that multiple positions have been chosen, including the supine, prone, and lateral decubitus

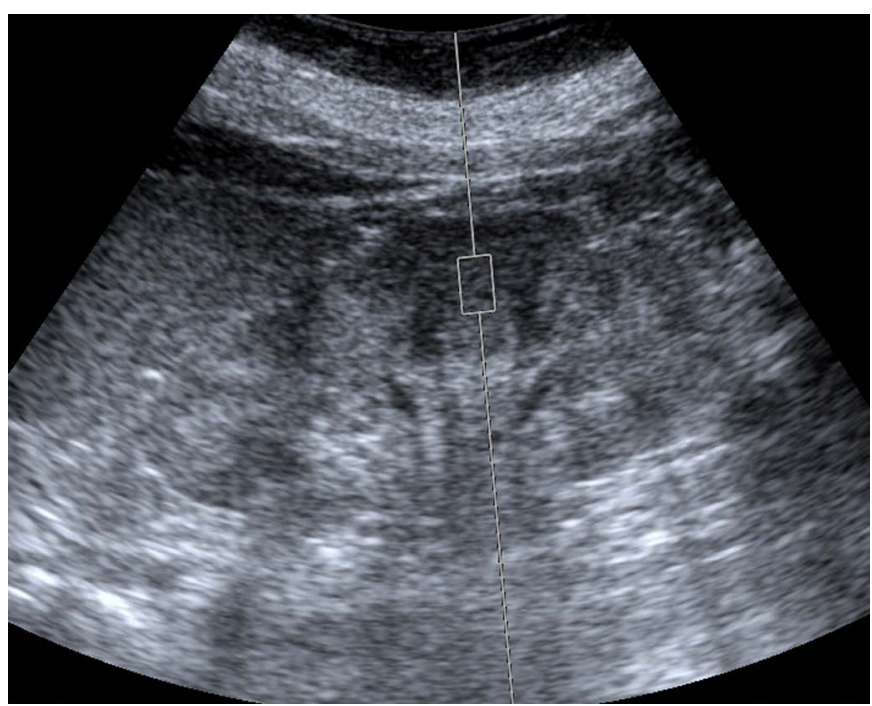

Fig. 1. Example of measuring shear-wave velocity. The measurement is performed in the middle third of the renal cortex on the sagittal plane. 
positions. The kidney is a deeply located retroperitoneal organ and is surrounded by anatomic structures with different depths from the renal capsule to the surface of the body. Therefore, different positions are associated with variations in scanning depth. Moreover, certain positions may require unrealistically large levels of compression in order to obtain clear images, especially in patients with a high body mass. Depth and compression have been proven to have a significant impact on SWV values $[19,20]$. Therefore, further investigation is warranted in order to develop recommendations regarding the choice of patient position.

\section{ARFI Quantification in Pediatric CKD}

The etiological spectrum of CKD is different in children and adults. Some diseases are very important in pediatric nephrology, but are much less frequently seen in adult patients, such as vesicoureteral reflux (VUR). VUR is the second most common cause of pediatric CKD, accounting for nearly a quarter of pediatric CKD patients [21]. In children with VUR, the kidneys are exposed to the risk of a urinary tract infection, which may lead to renal parenchymal damage and ultimately to the development of hypertension and chronic renal failure [22].

The first study of ARFI quantification in VUR was presented by Bruno et al. [7]. Twenty-eight children (age range, 9 to 16 years) with high-grade VUR and 16 age-matched healthy controls were included in the study, and all underwent ARFI quantification and scintigraphy. They noted that the highest ARFI values were observed in kidneys with secondary VUR, followed by kidneys with primary reflux, unaffected kidneys contralateral to kidneys experiencing reflux, and normal kidneys. The authors hypothesized that the fibrotic damage in CKD induced by VUR gave rise to the high SWV values observed in this series. Their preliminary results illustrate the possibility of including elastography in renal diagnostic imaging protocols.

However, in a recent study including 88 children with VUR, contradictory findings were reported. Goya et al. [15] found that the SWV values observed in the renal cortex decreased with increasing VUR severity and scintigraphy-assessed renal damage. Significantly higher SWV values were found in non-damaged kidneys, whereas severely damaged kidneys and high-grade refluxing kidneys had the lowest SWV values. Significant negative correlations were found between SWV values and both the renal scarring score and the VUR grade. The authors did not explain the disagreement with the previous study. These two studies employed a similar research design and ARFI imaging procedures but obtained completely opposite findings. Further investigation remains necessary.

\section{ARFI Quantification in Adult CKD}

Although CKD is a heterogeneous disease that consists of a group of various pathologies, the features common to CKD by definition include a progressive decrease in the glomerular filtration rate (GFR) and histological changes. Therefore, in studies of ARFI quantification in $C K D$, the primary concern should be to clarify the relationships of ARFI with renal dysfunction (CKD stage) and renal damage (pathologic alterations).

Three relevant studies have explored the correlations of SWV values with pathologic alterations but did not agree with each other. In a study of 163 adult patients, Hu et al. [10] reported that the mean SWV in kidneys with severe histologic impairment was significantly lower than in kidneys with mild histologic impairment, moderate histologic impairment, and controls. Additionally, SWV measurements showed a moderate negative correlation with pathologic parameters $(r=-0.422$ to -0.511$)$. Cui et al. [12] reported that the mean SWV values found in the subcapsular parenchyma of kidneys with various percentages of renal fibrosis $(<25 \%, 25 \%-50 \%,>50 \%)$ were higher than those of non-fibrotic kidneys, and that SWV values showed a positive linear correlation with fibrosis. In another CKD study that focused primarily on immunoglobulin A nephropathy (approximately 70\% of subjects), Wang et al. [11] found that SWV values did not show any significant correlations with renal fibrosis.

The definitive reason underlying these discrepancies remains unknown. However, these three studies employed different pathologic scoring systems. Hu et al. [10] used a much more complicated scoring system than the other two studies, while Cui et al. [12] assessed pathologic alterations of the kidney using only the parameter of fibrosis percentage. This difference may have contributed to the discrepancy in their findings. In a renal transplant study, Grenier et al. [23] reported that renal cortical stiffness was not correlated with any single pathologic score or the level of interstitial fibrosis, although a significant correlation was observed between cortical stiffness and global histological deterioration. Furthermore, considering the complex pathophysiology of CKD, any correlation between cortical SWV values and renal histological alterations may be subject to various influencing factors. In an animal study, Warner et al. [24] found that in a 6-week chronic renal arterial stenosis model, cortical stiffness was not significantly different in the treatment group and in the control group, despite histologic evidence of renal tissue fibrosis. They concluded that hemodynamic variables modulate kidney stiffness and may mask the presence of fibrosis.

In contrast, despite failing to predict pathologic alterations, ARFI quantification has been shown to have a significant correlation with GFR and CKD stage in several studies. In 2013, Guo et al. [8] 
Table 1. Summary of previous studies on ARFI quantification in CKD

\begin{tabular}{|c|c|c|c|c|c|c|c|c|c|c|c|c|c|c|}
\hline \multirow[b]{2}{*}{ Study } & \multicolumn{3}{|c|}{ Patient information } & \multicolumn{2}{|c|}{ Renal disease } & \multicolumn{6}{|c|}{ ARFI quantification } & \multicolumn{3}{|c|}{ Conclusion } \\
\hline & No. & $\begin{array}{l}\text { Age } \\
\text { (mean, } \\
\text { range) }\end{array}$ & $\begin{array}{c}\text { Sex } \\
\text { (M:F) }\end{array}$ & Etiology & $\begin{array}{l}\text { CKD } \\
\text { stage }\end{array}$ & $\begin{array}{l}\text { Diagnostic } \\
\text { evaluation }\end{array}$ & $\begin{array}{l}\text { Equip- } \\
\text { ment }\end{array}$ & $\begin{array}{l}\text { Patient } \\
\text { position }\end{array}$ & $\begin{array}{l}\text { Breath } \\
\text { held? }\end{array}$ & $\begin{array}{l}\text { Scanning } \\
\text { plane }\end{array}$ & $\begin{array}{l}\text { ROI location/ } \\
\text { Orientation }\end{array}$ & $\begin{array}{l}\text { No. of } \\
\text { measure- } \\
\text { ments }\end{array}$ & $\begin{array}{c}\text { Correlation } \\
\text { of SWV } \\
\text { with GFR/ } \\
\text { Histological } \\
\text { damage }\end{array}$ & $\begin{array}{c}\text { Correlation } \\
\text { of SWV with } \\
\text { specific renal } \\
\text { pathology }\end{array}$ \\
\hline $\begin{array}{l}\text { Bruno } \\
\text { et al. } \\
\text { (2013) } \\
{[7]}\end{array}$ & 28 & $\begin{array}{l}\text { Children } \\
(12.1 \\
9-16 \mathrm{yr})\end{array}$ & 17:11 & $\begin{array}{l}\text { Vesicoureteral } \\
\text { reflux ( } \geq \text { grade III) }\end{array}$ & NA & Scintigraphy & $\begin{array}{l}\text { Acuson } \\
\text { S2000 } \\
\text { with } \\
4-\mathrm{MHz} \\
\text { probe }\end{array}$ & Supine & Yes & $\begin{array}{l}\text { Longitudinal } \\
\text { plane }\end{array}$ & $\begin{array}{l}\text { Cortex at } \\
\text { upper, middle, } \\
\text { lower third/ } \\
\text { radial }\end{array}$ & 9 & NA/NA & $\begin{array}{l}\text { SWV values } \\
\text { increased in } \\
\text { kidneys with } \\
\text { vesicoureteral } \\
\text { reflux }\end{array}$ \\
\hline $\begin{array}{l}\text { Guo } \\
\text { et al. } \\
\text { (2013) } \\
{[8]}\end{array}$ & 64 & $\begin{array}{l}\text { Adults } \\
(64.7, \\
23-89 \\
\text { yr) }\end{array}$ & $37: 27$ & $\begin{array}{l}\text { CKD with } \\
\text { unknown } \\
\text { etiology }\end{array}$ & $\begin{array}{l}\text { I (11), } \\
\text { || (11), } \\
\text { II (20), } \\
\text { IV (10), } \\
\text { V (12) }\end{array}$ & $\begin{array}{l}\text { Serum } \\
\text { markers }\end{array}$ & $\begin{array}{l}\text { Acuson } \\
\text { S2000 } \\
\text { with 1-4- } \\
\mathrm{MHz} \\
\text { probe }\end{array}$ & Prone & NA & $\begin{array}{l}\text { Longitudinal } \\
\text { plane }\end{array}$ & $\begin{array}{l}\text { Parenchyma } \\
\text { (cortex and } \\
\text { medulla) at } \\
\text { middle third/ } \\
\text { NA }\end{array}$ & 5 & Positive/NA & NA \\
\hline $\begin{array}{l}\text { Asano } \\
\text { et al. } \\
\text { (2014) } \\
{[9]}\end{array}$ & 319 & $\begin{array}{c}\text { Adults } \\
(62.0, \\
17-93 \\
\text { yr) }\end{array}$ & $\begin{array}{l}198: \\
121\end{array}$ & $\begin{array}{l}\text { Glomerulo- } \\
\text { nephritis } \\
\text { (129), diabetic } \\
\text { nephropathy } \\
\text { (107), } \\
\text { nephrosclerosis } \\
\text { (83) }\end{array}$ & $\begin{array}{l}\text { I (29), } \\
\text { || (59), } \\
\text { I| (99), } \\
\text { IV (66), } \\
\text { V (66) }\end{array}$ & $\begin{array}{l}\text { Biopsy, serum } \\
\text { markers }\end{array}$ & $\begin{array}{l}\text { Acuson } \\
\text { S2000 } \\
\text { with 3.5- } \\
\text { MHz } \\
\text { probe }\end{array}$ & Prone & Yes & $\begin{array}{l}\text { Longitudinal } \\
\text { plane }\end{array}$ & $\begin{array}{l}\text { Cortex at } \\
\text { lower third/ } \\
\text { NA }\end{array}$ & $5-6$ & Positive/NA & NA \\
\hline $\begin{array}{l}\text { Hu et al. } \\
(2014) \\
{[10]}\end{array}$ & 163 & $\begin{array}{l}\text { Adults } \\
(41.3 \\
18-79 \\
\text { yr })\end{array}$ & $91: 72$ & $\begin{array}{l}\text { Glomerulo- } \\
\text { nephritis } \\
\text { (143), diabetic } \\
\text { nephropathy } \\
\text { (13), interstitial } \\
\text { disease (5), } \\
\text { nephrosclerosis } \\
\text { (2) }\end{array}$ & NA & $\begin{array}{l}\text { Biopsy, serum } \\
\text { markers }\end{array}$ & $\begin{array}{l}\text { Acuson } \\
\text { S2000 } \\
\text { with 1-4- } \\
\mathrm{MHz} \\
\text { probe }\end{array}$ & $\begin{array}{l}\text { Lateral } \\
\text { decu- } \\
\text { bitus }\end{array}$ & Yes & $\begin{array}{l}\text { Longitudinal } \\
\text { plane }\end{array}$ & $\begin{array}{l}\text { Cortex at } \\
\text { middle third/ } \\
\text { NA }\end{array}$ & 10 & $\begin{array}{l}\text { Positive/ } \\
\text { negative }\end{array}$ & NA \\
\hline $\begin{array}{l}\text { Wang } \\
\text { et al. } \\
\text { (2014) } \\
{[11]}\end{array}$ & 45 & $\begin{array}{l}\text { Adults } \\
(37.1 \\
18-72 \\
\text { yr })\end{array}$ & $23: 22$ & $\begin{array}{l}\text { Glomerulo- } \\
\text { nephritis (36), } \\
\text { nephrosclerosis } \\
\text { (6), diabetic } \\
\text { nephropathy (3) }\end{array}$ & $\begin{array}{l}\text { I (26), } \\
\text { || (7), } \\
\text { II| (6), } \\
\text { IV (6) }\end{array}$ & $\begin{array}{l}\text { Biopsy, serum } \\
\text { markers }\end{array}$ & $\begin{array}{l}\text { Acuson } \\
\text { S2000 } \\
\text { with 1-4- } \\
\mathrm{MHz} \\
\text { probe }\end{array}$ & $\begin{array}{c}\text { Lateral } \\
\text { decu- } \\
\text { bitus }\end{array}$ & Yes & $\begin{array}{l}\text { Longitudinal } \\
\text { plane }\end{array}$ & $\begin{array}{l}\text { Cortex at } \\
\text { middle third/ } \\
\text { radial }\end{array}$ & 15 & No/No & NA \\
\hline $\begin{array}{l}\text { Cui et al. } \\
(2014) \\
{[12]}\end{array}$ & 76 & $\begin{array}{l}\text { Children } \\
\text { and } \\
\text { adults } \\
\text { (40.4, } \\
11-75 \mathrm{yr})\end{array}$ & 43:33 & $\begin{array}{l}\text { CKD with } \\
\text { unknown } \\
\text { etiology }\end{array}$ & NA & Biopsy & $\begin{array}{l}\text { Acuson } \\
\text { S2000 } \\
\text { with 2-5- } \\
\text { MHz } \\
\text { probe }\end{array}$ & Prone & Yes & $\begin{array}{l}\text { Longitudinal } \\
\text { plane }\end{array}$ & NA/radial & 5 & NA/positive & NA \\
\hline $\begin{array}{l}\text { Sohn } \\
\text { et al. } \\
\text { (2014) } \\
{[13]}\end{array}$ & 30 & $\begin{array}{c}\text { Young } \\
\text { children } \\
(4.5, \\
0-23 \\
\text { mo })\end{array}$ & 25:5 & Hydronephrosis & NA & $\begin{array}{l}\text { Scintigraphy, } \\
\text { voiding } \\
\text { cystourethro- } \\
\text { graphy }\end{array}$ & $\begin{array}{l}\text { Acuson } \\
\text { S2000 } \\
\text { with 4-9- } \\
\mathrm{MHz} \\
\text { probe }\end{array}$ & NA & No & Axial plane & $\begin{array}{l}\text { Parenchyma } \\
\text { (cortex and } \\
\text { medulla) at } \\
\text { middle third/ } \\
\text { radial }\end{array}$ & 3 & NA/NA & $\begin{array}{l}\text { SWV values } \\
\text { increased in } \\
\text { kidneys with } \\
\text { high-grade } \\
\text { hydronephrosis }\end{array}$ \\
\hline $\begin{array}{l}\text { Yu et al. } \\
\text { (2014) } \\
{[14]}\end{array}$ & 120 & $\begin{array}{c}\text { Adults } \\
(50,32- \\
68 \mathrm{yr})\end{array}$ & $66: 54$ & $\begin{array}{l}\text { Diabetic } \\
\text { nephropathy }\end{array}$ & NA & $\begin{array}{l}\text { Serum and } \\
\text { urinary } \\
\text { markers }\end{array}$ & $\begin{array}{l}\text { Acuson } \\
\text { S2000 } \\
\text { with 1-4- } \\
\text { MHz } \\
\text { probe }\end{array}$ & NA & Yes & $\begin{array}{l}\text { Longitudinal } \\
\text { plane }\end{array}$ & $\begin{array}{l}\text { Cortex at } \\
\text { middle third/ } \\
\text { radial }\end{array}$ & 3 & NA/NA & $\begin{array}{l}\text { SWV values } \\
\text { increased } \\
\text { in kidneys } \\
\text { with diabetic } \\
\text { nephropathy }\end{array}$ \\
\hline $\begin{array}{l}\text { Goya } \\
\text { et al. } \\
(2015) \\
{[15]}\end{array}$ & 88 & $\begin{array}{c}\text { Children } \\
(5.6, \\
1-17 \mathrm{yr})\end{array}$ & $46: 42$ & $\begin{array}{l}\text { Vesicoureteral } \\
\text { reflux (grade I to } \\
\text { V) }\end{array}$ & NA & $\begin{array}{l}\text { Scintigraphy, } \\
\text { voiding } \\
\text { cystourethro- } \\
\text { graphy }\end{array}$ & $\begin{array}{l}\text { Acuson } \\
\text { S2000 } \\
\text { with } \\
1-4.5- \\
\mathrm{MHz} \\
\text { probe }\end{array}$ & $\begin{array}{l}\text { Lateral } \\
\text { decu- } \\
\text { bitus }\end{array}$ & Yes & $\begin{array}{l}\text { Longitudinal } \\
\text { plane }\end{array}$ & $\begin{array}{l}\text { Cortex at } \\
\text { upper, middle, } \\
\text { lower third/ } \\
\text { NA }\end{array}$ & 15 & NA/NA & $\begin{array}{l}\text { SWV values } \\
\text { decreased in } \\
\text { kidneys with } \\
\text { vesicoureteral } \\
\text { reflux and } \\
\text { DMSA-assessed } \\
\text { renal damage }\end{array}$ \\
\hline
\end{tabular}




\begin{tabular}{|c|c|c|c|c|c|c|c|c|c|c|c|c|c|c|}
\hline \multirow[b]{2}{*}{ Study } & \multicolumn{3}{|c|}{ Patient information } & \multicolumn{2}{|c|}{ Renal disease } & \multicolumn{6}{|c|}{ ARFI quantification } & \multicolumn{3}{|c|}{ Conclusion } \\
\hline & No. & $\begin{array}{l}\text { Age } \\
\text { (mean, } \\
\text { range) }\end{array}$ & $\begin{array}{l}\text { Sex } \\
(\mathrm{M}: \mathrm{F})\end{array}$ & Etiology & $\begin{array}{l}\text { CKD } \\
\text { stage }\end{array}$ & $\begin{array}{l}\text { Diagnostic } \\
\text { evaluation }\end{array}$ & $\begin{array}{l}\text { Equip- } \\
\text { ment }\end{array}$ & $\begin{array}{l}\text { Patient } \\
\text { position }\end{array}$ & $\begin{array}{l}\text { Breath } \\
\text { held? }\end{array}$ & $\begin{array}{l}\text { Scanning } \\
\text { plane }\end{array}$ & $\begin{array}{l}\text { ROI location/ } \\
\text { Orientation }\end{array}$ & $\begin{array}{l}\text { No. of } \\
\text { measure- } \\
\text { ments }\end{array}$ & $\begin{array}{c}\text { Correlation } \\
\text { of SWV } \\
\text { with GFR/ } \\
\text { Histological } \\
\text { damage }\end{array}$ & $\begin{array}{l}\text { Correlation } \\
\text { of SWV with } \\
\text { specific renal } \\
\text { pathology }\end{array}$ \\
\hline $\begin{array}{l}\text { Goya } \\
\text { et al. } \\
(2015) \\
{[16]}\end{array}$ & 114 & $\begin{array}{c}\text { Adults } \\
(57,23- \\
89 \mathrm{yr})\end{array}$ & $67: 47$ & $\begin{array}{l}\text { Diabetic } \\
\text { nephropathy }\end{array}$ & $\begin{array}{l}\text { I (42), } \\
\text { || (28), } \\
\text { I|| (13), } \\
\text { IV (16), } \\
\text { V (14) }\end{array}$ & $\begin{array}{l}\text { Serum and } \\
\text { urinary } \\
\text { markers }\end{array}$ & $\begin{array}{l}\text { Acuson } \\
\text { S2000 } \\
\text { with 1-4- } \\
\text { MHz } \\
\text { probe }\end{array}$ & $\begin{array}{c}\text { Supine } \\
\text { and lateral } \\
\text { decu- } \\
\text { bitus }\end{array}$ & Yes & $\begin{array}{l}\text { Longitudinal } \\
\text { plane }\end{array}$ & $\begin{array}{l}\text { Cortex at } \\
\text { upper, middle, } \\
\text { lower third/ } \\
\text { NA }\end{array}$ & 15 & Positive/NA & $\begin{array}{l}\text { SWV values } \\
\text { increased } \\
\text { in kidneys } \\
\text { with diabetic } \\
\text { nephropathy }\end{array}$ \\
\hline $\begin{array}{c}\text { Bob } \\
\text { et al. } \\
(2015) \\
{[17]}\end{array}$ & 46 & Adults & $28: 18$ & $\begin{array}{l}\text { Diabetic } \\
\text { nephropathy } \\
\text { (16), } \\
\text { nephrosclerosis } \\
\text { (12), glomerulo- } \\
\text { nephritis (9), } \\
\text { pyelonephritis } \\
\text { (3), unknown (6) }\end{array}$ & NA & $\begin{array}{l}\text { Serum } \\
\text { markers }\end{array}$ & $\begin{array}{l}\text { Acuson } \\
\text { S2000 } \\
\text { with 4-9- } \\
\text { MHz } \\
\text { probe }\end{array}$ & $\begin{array}{l}\text { Lateral } \\
\text { decu- } \\
\text { bitus }\end{array}$ & Yes & $\begin{array}{l}\text { Longitudinal } \\
\text { plane }\end{array}$ & $\begin{array}{l}\text { Parenchyma } \\
\text { (cortex and } \\
\text { medulla) at } \\
\text { middle third/ } \\
\text { radial }\end{array}$ & 5 & Positive/NA & NA \\
\hline $\begin{array}{l}\text { Takata } \\
\text { et al. } \\
\text { (2015) } \\
{[18]}\end{array}$ & 39 & $\begin{array}{c}\text { Adults } \\
(72,38- \\
86 \mathrm{yr})\end{array}$ & $25: 14$ & $\begin{array}{l}\text { End-stage renal } \\
\text { disease }\end{array}$ & NA & $\begin{array}{l}\text { Serum } \\
\text { markers }\end{array}$ & $\begin{array}{l}\text { Acuson } \\
\text { S2000 } \\
\text { with 1-4- } \\
\text { MHz } \\
\text { probe }\end{array}$ & NA & Yes & NA & NA/radial & 10 & NA/NA & $\begin{array}{l}\text { SWV values were } \\
\text { not associated } \\
\text { with advanced } \\
\text { renal impairment }\end{array}$ \\
\hline
\end{tabular}

ARFI, acoustic radiation force impulse; CKD, chronic kidney disease; ROI, region of interest; SWV, shear-wave velocity; GFR, glomerular filtration rate; NA, not available; DMSA, dimercaptosuccinic acid.

evaluated 64 adult CKD patients and reported lower SWV values in the renal parenchyma than were observed in 327 control subjects. In particular, a progressive reduction of SWV values was unexpectedly observed to correlate with increasing stages of CKD. Interestingly, this unexpected trend has also been reported in most subsequent studies $[9,10,16,17]$. The only exception is the study carried out by Wang et al. [11], in which no relation was found between SWV values and GFR or CKD stage. In contrast to CLD, kidneys with more advanced CKD tend to present lower cortical SWV values than are observed in early-stage disease. Many authors have suggested that hemodynamic alterations of the kidney may affect renal parenchymal elasticity during the progression of CKD.

In ARFI quantification for CLD, SWV values increase in more advanced stages of the disease as progressive interstitial fibrosis affects tissue elasticity. However, the dominant factor affecting ARFI quantification in CKD has not been clearly elucidated. The kidney is an organ with rich perfusion, receiving $20 \%$ of cardiac output despite only constituting $<1 \%$ of body mass [25]. Its distension and stiffness may therefore be significantly affected by renal blood perfusion. Under normal conditions, in order to provide the large quantity of oxygen necessary to support massive levels of reabsorption, the renal tubules are surrounded by a dense vascular plexus in both the cortex and medulla [25]. As CKD progresses, glomerular sclerosis, tubular atrophy, and peritubular fibrosis gradually become aggravated. Accordingly, the blood flow in the peritubular vascular plexus decreases. Considering the remarkable extent of damage in the microcirculation in advanced CKD, it is conceivable that renal blood flow may significantly influence SWV values, perhaps even more than interstitial fibrosis.

\section{Comparison of ARFI Quantification in CKD and CLD}

Although ARFI quantification is a reliable indicator of the severity of liver fibrosis in CLD, ARFI measurements in CKD remain quite controversial, and previous studies have reported variable results. These conflicting findings may be, to some extent, due to anatomical and physiological differences between the liver and kidney.

\section{Internal Architecture}

In contrast to the homogeneous echotexture of the liver, the kidney exhibits complex acoustic characteristics resulting from its heterogeneous histological structure, which consists of glomeruli, tubules, and stromal components. In addition, the regular arrangement of the internal tubular system gives rise to the anisotropic property of the kidney, whereas liver tissue is isotropic. In preclinical research, Gennisson et al. [26] found that cortical elasticity values were always higher when acquisitions were performed with the ultrasound main 
axis perpendicular to the main pyramid axis than when parallel, demonstrating the effect of renal anisotropy on renal stiffness.

\section{Blood Supply}

As stated above, the kidney is a richly perfused organ with a high perfusion pressure. In contrast, despite possessing a dual-source blood supply, the liver is mainly perfused by the low-pressure portal vein. Interestingly, under normal conditions, SWV values in the renal cortex are approximately twice as high as those obtained in hepatic tissue [27], which might be partially attributable to their different perfusion patterns. Thus, as disease progresses, diminished blood perfusion may influence tissue stiffness more strongly in CKD than in CLD.

\section{Age-Related Changes}

In studies of both children and adults, the liver did not show significant changes in tissue elasticity according to age $[28,29]$. However, distinct changes in renal cortical stiffness with age have been reported in both children and adults. Lee et al. [29] found that cortical SWV values for the kidney increased with age in children under 5 years old. In contrast, Bota et al. [20] reported that renal SWV values decreased with age in adults (18-30 years, $2.94 \pm 0.60$ $\mathrm{m} / \mathrm{sec}$; $31-50$ years, $2.26 \pm 0.82 \mathrm{~m} / \mathrm{sec}$; $51-65$ years, $2.48 \pm 0.8$ $\mathrm{m} / \mathrm{sec} ;>65$ years, $1.82 \pm 0.63 \mathrm{~m} / \mathrm{sec})$. In a correlation analysis, age was negatively correlated with renal SWV values as assessed by ARFI quantification $(r=-0.370)$.

\section{Future Prospects}

Considering the controversies regarding ARFI quantification in CKD, further studies are urgently necessary in order to clarify several important issues.

First, the mechanism underlying the impact of renal hemody-namics on tissue elasticity remains unknown. Asano et al. [9] reported that SWV values decreased concurrently with decreases in the estimated GFR. Meanwhile, low SWV values were obtained in patients with a high brachial-ankle pulse wave velocity. Since a high brachial-ankle pulse wave velocity represents the progression of arteriosclerosis in the large vessels, the authors concluded that the reduction of elasticity subsequent to the diminution of blood flow was likely to be the factor most strongly influencing the SWV in the kidneys.

Moreover, etiology-specific applications of ARFI quantification may be more valuable. For example, in a study of diabetic nephropathy, Goya et al. [16] found SWV values for the kidneys of $2.87 \mathrm{~m} / \mathrm{sec}$, $3.14 \mathrm{~m} / \mathrm{sec}, 2.95 \mathrm{~m} / \mathrm{sec}, 2.68 \mathrm{~m} / \mathrm{sec}$, and $2.55 \mathrm{~m} / \mathrm{sec}$ in patients with stage $1,2,3,4$, and 5 diabetic nephropathy, respectively, in comparison with $2.35 \mathrm{~m} / \mathrm{sec}$ for healthy controls. Using $2.43 \mathrm{~m} /$ sec as the threshold value for predicting diabetic nephropathy, they obtained diagnostic sensitivity and specificity values of $84.1 \%$ and $67.3 \%$, respectively.

Finally, the natural course of renal SWV in the normal population is not fully understood. Age has been well established as a confounding factor for ARFI quantification in CKD, but it remains unclear to what extent age can mask the presence and progression of pathologic alterations in CKD patients. As an extreme example, Takata et al. [18] reported that no differences were identified between age-matched non-CKD controls and end-stage renal disease patients, reflecting the non-negligible impact of aging on kidney elasticity. Thus, age-adjustment of renal elasticity may be necessary in order to apply ARFI quantification to CKD.

\section{Conclusion}

In summary, the quantification of tissue stiffness using ARFI is more complex for the kidney than the liver. It should be studied more both in animal models and in clinical patients, in order to better understand the pathophysiological mechanisms underlying renal elasticity. In addition, not all previous studies are comparable because they used different procedures [30]. Therefore, further research is warranted to improve this technique and to develop standardized guidelines.

ORCID: Liang Wang: http://orcid.org/0000-0003-4568-2052

\section{Conflict of Interest}

No potential conflict of interest relevant to this article was reported.

\section{References}

1. Shiina T, Nightingale KR, Palmeri ML, Hall TJ, Bamber JC, Barr RG, et al. WFUMB guidelines and recommendations for clinical use of ultrasound elastography: Part 1: basic principles and terminology. Ultrasound Med Biol 2015;41:1126-1147.

2. Barr RG, Nakashima K, Amy D, Cosgrove D, Farrokh A, Schafer F, et al. WFUMB guidelines and recommendations for clinical use of ultrasound elastography: Part 2: breast. Ultrasound Med Biol 2015;41:1148-1160.

3. Ferraioli G, Filice C, Castera L, Choi BI, Sporea I, Wilson SR, et al. WFUMB guidelines and recommendations for clinical use of ultrasound elastography: Part 3: liver. Ultrasound Med Biol 2015;41:1161-1179.

4. Lopez-Novoa JM, Rodriguez-Pena AB, Ortiz A, Martinez-Salgado C, Lopez Hernandez FJ. Etiopathology of chronic tubular, glomerular and renovascular nephropathies: clinical implications. J Transl Med 2011;9:13.

5. Levey AS, de Jong PE, Coresh J, El Nahas M, Astor BC, Matsushita K, 
et al. The definition, classification, and prognosis of chronic kidney disease: a KDIGO Controversies Conference report. Kidney Int 2011;80:17-28.

6. Jha V, Garcia-Garcia G, Iseki K, Li Z, Naicker S, Plattner B, et al. Chronic kidney disease: global dimension and perspectives. Lancet 2013;382:260-272.

7. Bruno C, Caliari G, Zaffanello M, Brugnara M, Zuffante M, Cecchetto $M$, et al. Acoustic radiation force impulse (ARFI) in the evaluation of the renal parenchymal stiffness in paediatric patients with vesicoureteral reflux: preliminary results. Eur Radiol 2013;23:3477-3484.

8. Guo LH, Xu HX, Fu HJ, Peng A, Zhang YF, Liu LN. Acoustic radiation force impulse imaging for noninvasive evaluation of renal parenchyma elasticity: preliminary findings. PLoS One 2013;8:e68925.

9. Asano K, Ogata A, Tanaka K, Ide Y, Sankoda A, Kawakita C, et al. Acoustic radiation force impulse elastography of the kidneys: is shear wave velocity affected by tissue fibrosis or renal blood flow? J Ultrasound Med 2014;33:793-801.

10. Hu Q, Wang XY, He HG, Wei HM, Kang LK, Qin GC. Acoustic radiation force impulse imaging for non-invasive assessment of renal histopathology in chronic kidney disease. PLoS One 2014;9:e115051.

11. Wang L, Xia P, Lv K, Han J, Dai Q, Li XM, et al. Assessment of renal tissue elasticity by acoustic radiation force impulse quantification with histopathological correlation: preliminary experience in chronic kidney disease. Eur Radiol 2014;24:1694-1699.

12. Cui G, Yang Z, Zhang W, Li B, Sun F, Xu C, et al. Evaluation of acoustic radiation force impulse imaging for the clinicopathological typing of renal fibrosis. Exp Ther Med 2014;7:233-235.

13. Sohn B, Kim MJ, Han SW, Im YJ, Lee MJ. Shear wave velocity measurements using acoustic radiation force impulse in young children with normal kidneys versus hydronephrotic kidneys. Ultrasonography 2014;33:116-121.

14. Yu N, Zhang $Y, X u Y$. Value of virtual touch tissue quantification in stages of diabetic kidney disease. J Ultrasound Med 2014;33:787792.

15. Goya C, Hamidi C, Ece A, Okur MH, Tasdemir B, Cetincakmak MG, et al. Acoustic radiation force impulse (ARFI) elastography for detection of renal damage in children. Pediatr Radiol 2015;45:55-61.

16. Goya C, Kilinc F, Hamidi C, Yavuz A, Yildirim Y, Cetincakmak MG, et al. Acoustic radiation force impulse imaging for evaluation of renal parenchyma elasticity in diabetic nephropathy. AJR Am J Roentgenol 2015;204:324-329.

17. Bob F, Bota S, Sporea I, Sirli R, Popescu A, Schiller A. Relationship between the estimated glomerular filtration rate and kidney shear wave speed values assessed by acoustic radiation force impulse elastography: a pilot study. J Ultrasound Med 2015;34:649-654.

18. Takata T, Koda M, Sugihara T, Sugihara S, Okamoto T, Miyoshi K, et al. Renal shear wave velocity by acoustic radiation force impulse did not reflect advanced renal impairment. Nephrology (Carlton) 2015 Dec 14 [Epub]. http://dx.doi.org/10.1111/nep.12701.

19. Syversveen T, Midtvedt K, Berstad AE, Brabrand K, Strom EH, Abildgaard $A$. Tissue elasticity estimated by acoustic radiation force impulse quantification depends on the applied transducer force: an experimental study in kidney transplant patients. Eur Radiol 2012;22:2130-2137.

20. Bota S, Bob F, Sporea I, Sirli R, Popescu A. Factors that influence kidney shear wave speed assessed by acoustic radiation force impulse elastography in patients without kidney pathology. Ultrasound Med Biol 2015;41:1-6.

21. Ardissino G, Dacco V, Testa S, Bonaudo R, Claris-Appiani A, Taioli E, et al. Epidemiology of chronic renal failure in children: data from the ItalKid project. Pediatrics 2003;111(4 Pt 1):e382-e387.

22. Williams G, Fletcher JT, Alexander SI, Craig JC. Vesicoureteral reflux. J Am Soc Nephrol 2008; 19:847-862.

23. Grenier N, Poulain S, Lepreux S, Gennisson JL, Dallaudiere B, Lebras $Y$, et al. Quantitative elastography of renal transplants using supersonic shear imaging: a pilot study. Eur Radiol 2012;22:21382146.

24. Warner L, Yin M, Glaser KJ, Woollard JA, Carrascal CA, Korsmo $M J$, et al. Noninvasive in vivo assessment of renal tissue elasticity during graded renal ischemia using MR elastography. Invest Radiol 2011;46:509-514.

25. Munger KA, Kost CK Jr, Brenner BM, Maddox DA. The renal circulations and glomerular ultrafiltration. In: Taal MW, Chertow GM, Marsden PA, Skorecki K, Yu AS, Brenner BM, eds. Brenner and Rector's the kidney. 9th ed. Philadelphia, PA: Elsevier, 2012;94-137.

26. Gennisson JL, Grenier N, Combe C, Tanter M. Supersonic shear wave elastography of in vivo pig kidney: influence of blood pressure, urinary pressure and tissue anisotropy. Ultrasound Med Biol 2012;38:1559-1567.

27. Goertz RS, Amann K, Heide R, Bernatik T, Neurath MF, Strobel D. An abdominal and thyroid status with acoustic radiation force impulse elastometry: a feasibility study: acoustic radiation force impulse elastometry of human organs. Eur J Radiol 2011;80:e226-e230.

28. Liao LY, Kuo KL, Chiang HS, Lin CZ, Lin YP, Lin CL. Acoustic radiation force impulse elastography of the liver in healthy patients: test location, reference range and influence of gender and body mass index. Ultrasound Med Biol 2015;41:698-704.

29. Lee MJ, Kim MJ, Han KH, Yoon CS. Age-related changes in liver, kidney, and spleen stiffness in healthy children measured with acoustic radiation force impulse imaging. Eur J Radiol 2013;82:e290-e294.

30. Zaffanello M, Piacentini G, Bruno C, Brugnara M, Fanos V. Renal elasticity quantification by acoustic radiation force impulse applied to the evaluation of kidney diseases: a review. J Investig Med 2015;63:605-612. 